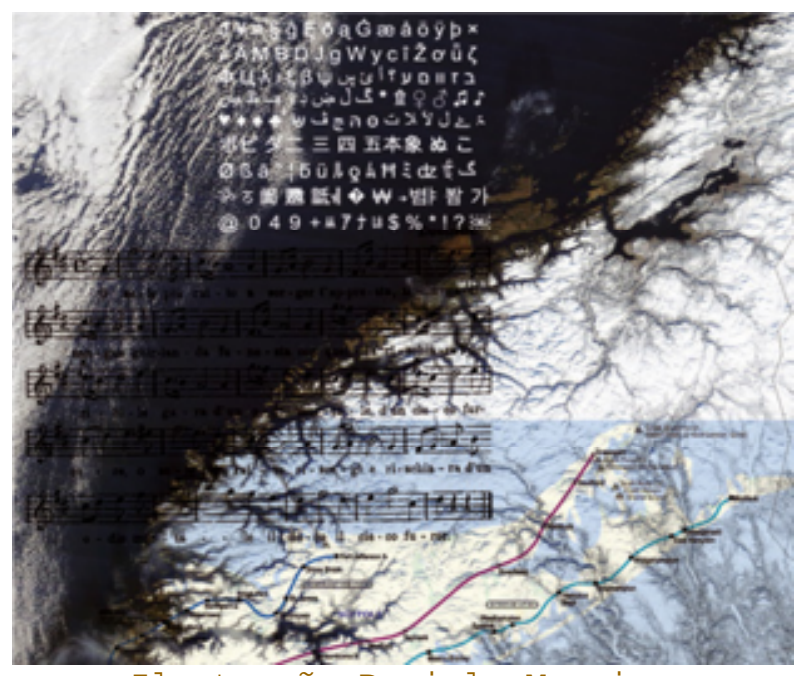

Ilustração Daniela Moreira

\title{
Sem título
}

\section{Fábio Gabriel Martins}

Aluno de Pós-graduação em Estudos Literários na FALE/UFMG.

Procura-se uma palavra que não queira ser escrita. Uma que à nossa revelia se recuse a habitar a folha, os muros, a tela. Aquela, que teima em ser só voz. Intrigados, os olhos que não a alcançam, ofereceram-lhe alfabetos: da direita para a esquerda, da esquerda para a direita, no formato hieroglífico, ideogramático, .... , cifrado ou simples. Ela dá de ombros. Essa palavra procurada não quer ser representada. Muitos poetas já a tiveram na ponta da língua, e incapazes, renderamse a uma outra similar palavra, camuflada no som. Mil milhões de teorias a deixam escapar todos os dias. Quem porventura a encontrar por gentileza entre em contato com nossa produção. Gratificação: um Aurélio.

\section{Quero escrever em islandês}

Na Islândia lêm-se muitos livros. Bjork é uma cantora islandesa que canta em inglês. Lá existem 499 matizes de branco percebidos pelos esquimós quando olham para a neve. No Brasil lê-se muito pouco. 
Txt: Leituras Transdisciplinares de Telas e Textos, Belo Horizonte, v.3, n.5, p.98-99, 2007

Aqui os 4999 matizes de verde pouco importam e a música produzida tomou o lugar do livro. Ninguém compra livros com letras de música. Ouve-se.

Será que nossa alegria pachorrenta é conhecida dos esquimós? 